\section{Using Cultural Practices and Cultivar Resistance to Manage Phytophthora Crown Rot on Summer Squash}

\author{
Michael D. Meyer and Mary K. Hausbeck ${ }^{1}$ \\ Department of Plant Pathology, Michigan State University, Plant Biology \\ Laboratories, 612 Wilson Road, East Lansing, MI 48824
}

Additional index words. Phytophthora blight, Phytophthora capsici, Cucurbita pepo, cultural management practices

\begin{abstract}
The effects of bed height, mulches, composted poultry litter, and cultivars on Phytophthora crown rot, caused by Phytophthora capsici Leonian, of summer squash (Cucurbita pepo L.) were evaluated in the absence of fungicide applications. The experimental design was a split-split-split plot arrangement of a randomized complete block. Bed height (flat or raised) was the main plot treatment. Mulches (bare soil, wheat straw, or plastic) were subplot treatments. Composted poultry litter applications ( 0 or $4.5 \mathrm{t} \cdot \mathrm{ha}^{-1}$ ) were sub-subplot treatments. Squash cultivars (Cougar or Payroll) were subsub-subplot treatments. Incidence of plant death (\%) was assessed from 0 to 35 days postinoculation (dpi) with $\boldsymbol{P}$. capsici. Plant death 35 dpi and area under the disease progress curve (AUDPC)differed significantly $(P<\mathbf{0 . 0 0 0 1})$ between the cultivars Cougar and Payroll. Mean plant death 35 dpi was $87 \%$ for 'Payroll' and $99 \%$ for 'Cougar'. The bed height $\times$ cultivar interaction was also significant $(P=0.0018)$ in the analyses of variance for plant death and AUDPC. Plant death at 35 dpi and AUDPC for 'Payroll' were greater in flat beds than raised beds. Disease was unaffected by the main effects of bed height, mulch type, or application of poultry litter. Thirty-two summer squash cultivars and 10 germplasm accessions were also evaluated for resistance to Phytophthora crown rot in a separate greenhouse trial. Crown rot severity was rated on a 1 (no symptoms) to 5 (plant death) scale at $18 \mathrm{dpi}$. Crown rot severity differed significantly $(P<0.0001)$ among cultivars and germplasm accessions. Crown rot severity averaged 4.3 on commercial cultivars and 2.2 on germplasm accessions. Crown rot was least severe on the commercial cultivar Spineless Beauty (mean rating $=2.9$ ). No disease developed on four accessions of Cucurbita moschata previously reported to be crown rot-resistant.
\end{abstract}

Phytophthora capsici Leonian is an economically important soilborne pathogen of summer squash (Cucurbita pepo L.) and other vegetable crops in many areas of the world (Babadoost, 2004, 2005; Babadoost and Zitter, 2009; Hausbeck and Lamour, 2004; Hwang and Kim, 1995). Phytophthora capsici causes fruit, crown, and root rot as well as foliar blight (Babadoost, 2004, 2005; Babadoost and Zitter, 2009; Hausbeck and Lamour, 2004). Phytophthora crown rot is particularly severe because infections result in plant death and significant crop loss. Management of Phytophthora crown rot requires an integrated approach (Babadoost, 2005; Hausbeck and Lamour, 2004; Hwang and Kim, 1995; Ristaino and

Received for publication 7 Feb. 2012. Accepted for publication 1 May 2012.

This research is based on work supported by the USDA NIFA Special Research Grant Award Numbers 2010-34381-21286 and 2009-34572-19990, MSU SWMREC Award Number FY 10-02, and the Pickle and Pepper Research Committee of Michigan State University, Pickle Packers International, Inc.

We thank Brian Cortright, Mitch Wood, Adam Cortright, and Alex Cook for technical assistance and Pablo Reeb for statistical advice.

${ }^{1}$ To whom reprint requests should be addressed; e-mail hausbec1@anr.msu.edu.
2001). Resistance to $P$. capsici from the wild species Cucurbita lundelliana was introgressed into 19 winter squash breeding lines (Kabelka et al., 2007). An inheritance study indicated that resistance to Phytophthora crown rot derived from $C$. lundelliana and C. okeechobeenesis subsp. okeechobeenesis is conferred by three dominant genes (Padley et al., 2009). Resistance to P. capsici has not been incorporated into commercial breeding lines, and all cucurbit cultivars are considered susceptible to Phytophthora crown rot (Babadoost, 2004, 2005; Hausbeck and Lamour, 2004). However, cultivars may differ slightly in their reactions to $P$. capsici, and growing less susceptible cultivars in combination with other cultural management practices could be used to improve management of Phytophthora crown rot.

Cultural management practices that reduce soil saturation or prevent splash dispersal of $P$. capsici propagules can affect Phytophthora crown rot development. Growing plants on raised beds improves water drainage, thereby limiting the conditions favorable for disease development. Phytophthora blight incidence on pepper was $18 \%$ in flat beds and $5 \%$ in beds raised $45 \mathrm{~cm}$ (Hwang and Kim, 1995). Similarly, plant death of zucchini in a field naturally infested with $P$. capsici was greater in flat beds than raised beds (Hausbeck and Lamour, 2004). Covering planting beds with plastic mulch can reduce splash dispersal of $P$. capsici from the soil to susceptible plant tissues (Ristaino et al., 1997). However, in some cases, plastic mulches increased the spread of Phytophthora blight within a row because $P$. capsici propagules are readily dispersed in water on the surface of plastic mulches (Ristaino et al., 1997; Springer and Johnston, 1982). Organic mulches have also been effective at reducing splash dispersal of $P$. capsici. Chopped wheat straw dispersed between planting rows reduced the spread of Phytophthora blight on pepper (Ristaino et al., 1997). Altering cultural practices may not affect Phytophthora blight development on vining crops like watermelon, which grow off of raised beds and come into contact with the soil between rows (Kousik et al., 2011). Similarly, the costs associated with raised bed, plasticulture may not be feasible in crops grown for processing because crop values are lower.

Application of organic soil amendments such as composted animal manures has been used to suppress diseases caused by various soilborne pathogens including $P$. capsici (Zinati, 2005). Compost water extracts from livestock manures inhibited zoospore germination, germ tube formation, and mycelial growth of $P$. capsici (Sang et al., 2010). In a separate study, manure application reduced the viability of $P$. capsici oospores (NúñezZofío et al., 2011). Applications of compost water extracts increased the expression of numerous pathogenesis-related genes in pepper plants and reduced disease caused by $P$. capsici (Sang et al., 2010). Amending potting mix with composted sewage sludge reduced the incidence of Phytophthora crown rot on pepper by $42 \%$ in a greenhouse trial 
(Lumsden et al., 1983). Application of semicomposted horse and poultry manure followed by plastic mulching increased soil microbial activity and reduced the incidence of Phytophthora crown and root rot on pepper in Spain (Núñez-Zofío et al., 2011).

Combining cultural management practices, including planting cultivars with resistance to $P$. capsici, could be used to improve the management of Phytophthora crown rot on summer squash. Few large-scale field trials have evaluated the integrated use of multiple cultural practices to manage Phytopththora crown rot of summer squash. The objective of this field study was to evaluate the effects of bed height, mulches, composted poultry litter, and cultivars on Phytophthora crown rot of summer squash in the absence of fungicides. Thirty-two summer squash cultivars and 10 germplasm accessions were also evaluated for their reaction to Phytophthora crown rot in a separate greenhouse study.

\section{Materials and Methods}

Inoculum preparation. Phytophthora capsici isolate 12889 (mating type A1) obtained from the culture collection of M.K. Hausbeck at Michigan State University was used to inoculate plants in this study. Phytophthora capsici isolate 12889 was originally collected from bell pepper and is insensitive to mefenoxam. Cultures were grown on unclarified V8 juice agar (UCV8) at room temperature $\left(21 \pm 2{ }^{\circ} \mathrm{C}\right)$ under constant fluorescent light. Phytophthora capsici-infested millet seed was produced as described by QuesadaOcampo et al. (2009).

Field evaluation. Two separate field experiments were conducted at the Michigan State University Southwest Michigan Research and Extension Center in Benton Harbor. The previous crop was yellow straightneck summer squash (C. pepo L.). The soil type was Spinks loamy fine sand (sandy, mixed, mesic Lamellic Hapludalfs). The experimental design was a split-split-split plot arrangement of a randomized complete block with four replicates. Bed types (flat or raised) were main plots. Beds were spaced $1.7 \mathrm{~m}$ apart. Mulches (none, $\approx 8 \mathrm{~cm}$ of wheat straw, or black plastic) were applied to subplots. Composted poultry litter (Nature's Supreme Poultry Fertilizer Crumbles; Herbruck Poultry Ranch Inc., Saranac, MI) was applied at a rate of 0 or $4.5 \mathrm{t} \cdot \mathrm{ha}^{-1}$ to sub-subplots. Poultry litter was incorporated to a soil depth of 5 to $8 \mathrm{~cm}$ before mulch application. Summer squash cultivars Cougar (Harris Moran Seed Co., Modesto, CA) and Payroll (Rogers Brand Vegetable Seeds, Syngenta Seeds, Inc., Boise, ID) were grown in sub-sub-subplots. These cultivars were selected based on their reactions to Phytophthora crown rot in a field evaluation in New York (Camp et al., 2009). Seeds were planted $0.46 \mathrm{~m}$ apart within beds. An experimental unit was one 4.6-m-long bed with 10 plants. Planting dates were 3 June 2011 (Trial 1) and 13 June 2011 (Trial 2).

Plants were inoculated at the first true-leaf stage with $1 \mathrm{~g}$ of $P$. capsici-infested millet seeds. Infested millet seeds were placed in a 3 -cm-deep hole near the crown of each plant and covered with soil. Plants were irrigated twice weekly for 6 to $7 \mathrm{~h}$ to promote disease development. Disease incidence, defined as the percentage of wilting and dead plants in each plot, was measured at 7-d intervals from 0 to $35 \mathrm{~d}$ post-inoculation (dpi). Area under the disease progress curve (AUDPC) values for disease incidence were calculated according to the formula presented by Shaner and Finney (1977). Squash fruit were harvested from healthy appearing plants in each plot every 3 or $4 \mathrm{~d}$ over a 2 -week period and weighed.

Greenhouse evaluation of cultivars and germplasm accessions. Thirty-two summer squash cultivars and 10 germplasm accessions were evaluated for their susceptibility to Phytophthora crown rot in two replicated greenhouse trials. Accessions were obtained from the USDA-ARS Plant Genetic Resources Conservation Unit in Griffin, GA, and the USDA-ARS North Central Regional Plant Introduction Station in Ames, IA. Accessions were selected based on previous studies of Phytophthora crown rot resistance (Chavez et al., 2011; Padley et al., 2008). Trials were conducted in May and June 2011 at the Michigan State University Horticulture Research and Teaching Center in Holt. The experimental design was completely randomized with eight replicates. An experimental unit was one plant grown in a 10-cm-diameter pot containing soilless potting mix (BACCTO High Porosity Professional Potting Mix; Michigan Peat Co., Houston, TX). Plants were inoculated with $1 \mathrm{~g}$ of $P$. capsiciinfested millet seeds as previously described for field trials. Disease severity was assessed at 18 dpi. Each plant was visually assessed using a 1 to 5 scale, where $1=$ no symptoms; $2=$ lower leaves wilted with slight constriction of the stem; 3 = all leaves wilted with constriction and slight discoloration of the stem; $4=$ all leaves wilted and crown rotted with visible sporulation on the stem surface; and $5=$ plant dead.

Pathogen confirmation. Approximately 5\% of symptomatic plants in field and greenhouse trials were sampled for pathogen confirmation. Symptomatic plants were arbitrarily selected and sheared at the soil line with hand pruners. Crown sections were surface-disinfested with a 70\% ethanol solution and blotted dry with paper toweling. Four pieces of tissue were excised from each crown and plated on UCV8 amended with $25 \mathrm{ppm}$ of benomyl, $100 \mathrm{ppm}$ of ampicillin, $30 \mathrm{ppm}$ of rifampicin, and $100 \mathrm{ppm}$ of pentachloronitrobenzene. Colonies were identified as $P$. capsici using morphological characteristics and a key developed by Waterhouse (1963). Mating type and sensitivity to mefenoxam were also determined for each isolate and compared with the phenotype of isolate 12889 .

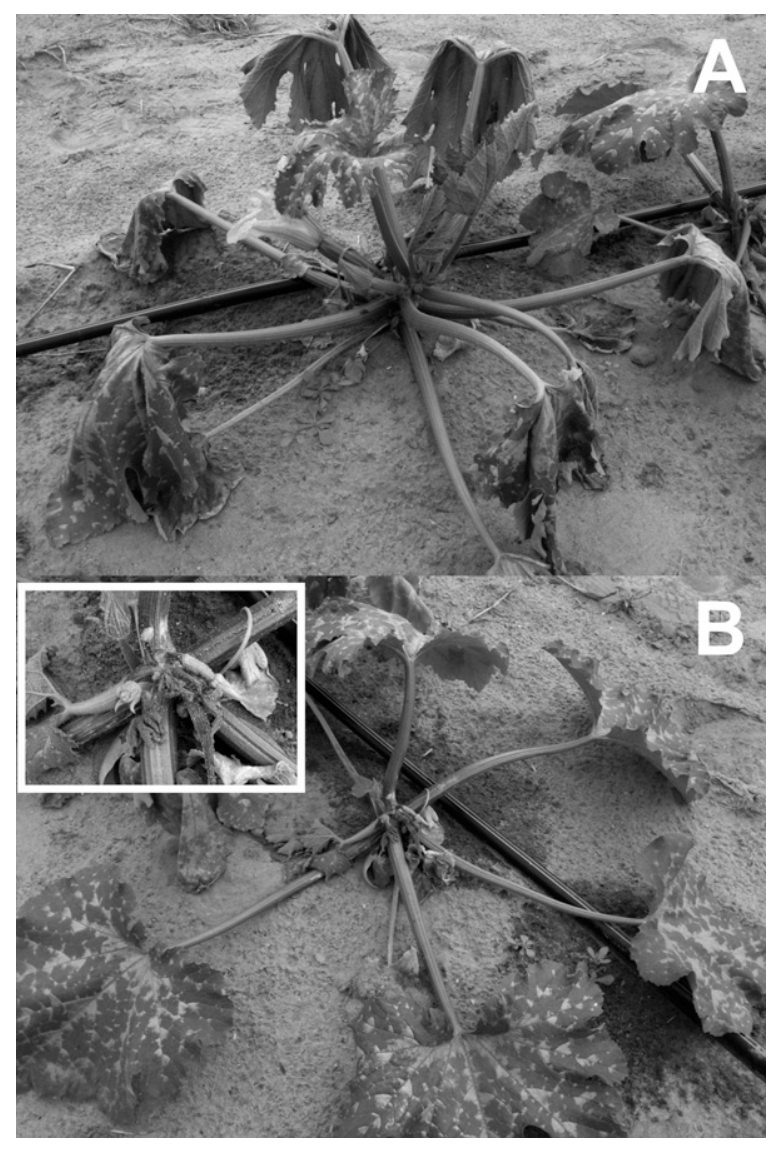

Fig. 1. Disease symptoms on summer squash plants inoculated with Phytophthora capsici: (A) typical wilting preceding plant death and (B) death of the primary growing point (enlarged in the inset), whereas lower leaves remain unaffected. 


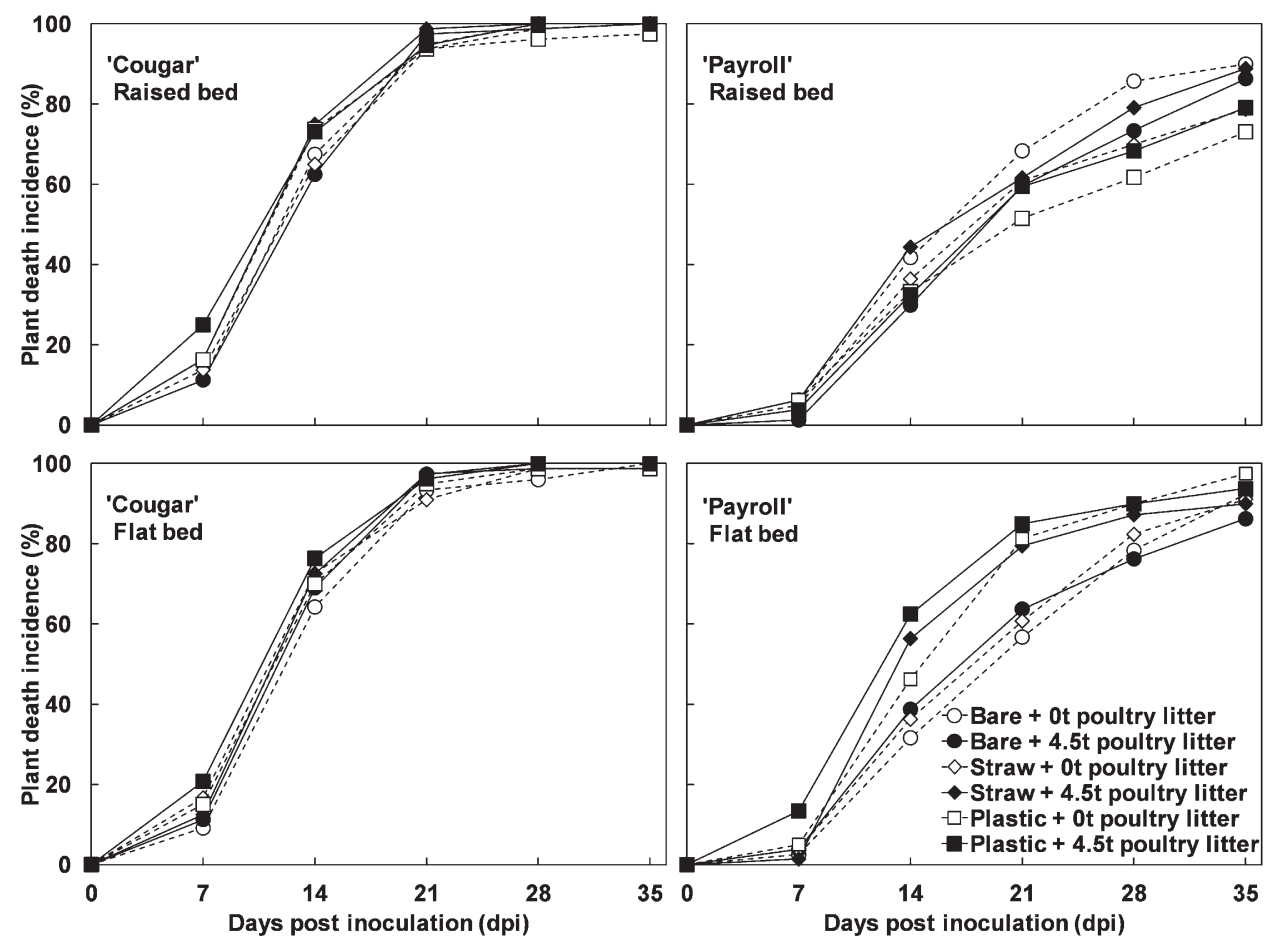

Fig. 2. Plant death of summer squash cultivars Cougar and Payroll after inoculation with Phytophthora capsici. Plants were grown in flat or raised beds covered

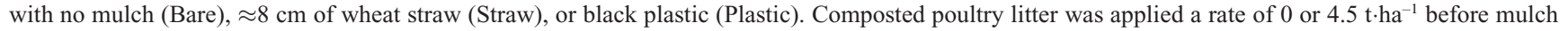
application.

Statistical analysis. All analyses were done using SAS, Version 9.2 (SAS Institute, Cary, NC). For field trials, final incidence of plant death 35 dpi and AUDPC were analyzed separately by analysis of variance (ANOVA) in the Proc Mixed procedure. Trials and blocks were considered random variables. Bed height, mulch type, poultry litter applications, and cultivars were considered fixed variables. For greenhouse trials, final crown rot severity ratings 18 dpi were analyzed by ANOVA using the Proc Mixed procedure. Cultivars were considered fixed variables. All effects were declared significant at $P \leq 0.01$ unless otherwise stated. Slice statements were used to test simple main effects when two-way interactions were significant. Residuals were tested for normality using the Shapiro-Wilk statistic in the Proc Univariate procedure. Residuals were plotted against predicted values using the Proc Gplot procedure to assess homogeneity of error variance.

\section{Results}

Field evaluation. Plants were highly susceptible to $P$. capsici at all growth stages from expansion of the first true-leaf stage to full maturity. Plants with Phytophthora crown and root rot rapidly wilted and died (Fig. 1A). Crown rot symptoms were also observed in the absence of root rot. The primary growing point of plants with crown rot only was killed but lower leaves remained green and turgid (Fig. 1B). All plants with Phytophthora crown and root rot symptoms eventually died. Phytophthora

Table 1. Mean squares for treatment sources of variation from analyses of variance of plant death incidence $35 \mathrm{~d}$ post-inoculation (dpi) and area under the disease progress curve (AUDPC) in field trails evaluating the effects of bed height, mulches, composted poultry litter, and cultivars on Phytophthora crown rot of summer squash.

\begin{tabular}{lccc}
\hline & & \multicolumn{2}{c}{ Mean square $^{\mathrm{z}}$} \\
\cline { 3 - 4 } Source of variation & df & Plant death $(\%) 35$ dpi & AUDPC $^{\mathrm{y}}$ \\
\hline Bed $^{\mathrm{x}}$ & 1 & 954 & 706,645 \\
Mulch $^{\mathrm{w}}$ & 2 & 59 & 201,433 \\
Mulch $\times$ bed & 2 & 396 & 470,689 \\
Litter $^{\mathrm{v}}$ & 1 & 9 & 310,498 \\
Litter $\times$ bed & 1 & 204 & 109,491 \\
Litter $\times$ mulch & 2 & 101 & 155,682 \\
Litter $\times$ mulch $\times$ bed & 2 & 25 & 64,856 \\
Cultivar & 1 & $7,154^{* * *}$ & $21,404,059^{* * * *}$ \\
Cultivar $\times$ bed & 1 & $1,045^{* *}$ & $786,944^{* *}$ \\
Cultivar $\times$ mulch & 2 & 15 & 2,320 \\
Cultivar $\times$ mulch $\times$ bed & 2 & 320 & 439,519 \\
Cultivar $\times$ litter & 1 & 2 & 3,614 \\
Cultivar $\times$ litter $\times$ bed & 1 & 165 & 92,796 \\
Cultivar $\times$ litter $\times$ mulch & 2 & 80 & 89,620 \\
Cultivar $\times$ litter $\times$ mulch $\times$ bed & 2 & 20 & 7,500 \\
Coefficient of variation $(\%)$ & - & 13 & 27 \\
\hline
\end{tabular}

${ }^{2}$ Corresponding mean square is statistically significant at $* * P \leq 0.01$ or $* * * P \leq 0.001$.

${ }^{y}$ AUDPC was calculated for plant death incidence assessed at 7-d intervals from 0 to 35 dpi.

${ }^{\times}$Bed height (flat or raised) was the main plot treatment.

${ }^{\text {w} M u l c h e s ~(n o n e, ~ w h e a t ~ s t r a w, ~ o r ~ b l a c k ~ p l a s t i c) ~ w e r e ~ t h e ~ s u b p l o t ~ t r e a t m e n t . ~}$

${ }^{\mathrm{v}}$ Composted poultry litter application was the sub-subplot treatment.

u'Squash cultivar (Cougar or Payroll) was the sub-sub-subplot treatment.

capsici with the same phenotype as isolate 12889 was consistently isolated from symptomatic plants.

No combination of cultural practices adequately controlled Phytophthora crown rot. Incidence of plant death caused by P. capsici approached $100 \%$ in all plots (Fig. 2). Plant death 35 dpi and AUDPC differed significantly $(P<0.0001)$ among cultivars (Table 1). Disease was unaffected by bed height, mulches, or poultry litter applications. Plant death 35 dpi was $87 \%$ for 'Payroll' and $99 \%$ for 'Cougar' averaged across all other treatments (Table 2). The bed $\times$ cultivar interaction term also was significant $(P=0.0018)$ in the ANOVAs for plant death and AUDPC (Table 1). Complete death of 'Cougar' occurred regardless of bed height (Table 2). Plant death of 'Payroll' was greater in flat beds than in 
raised beds (Table 2). Yield data were not analyzed because almost all plants in both trials died before bearing fruit.

Greenhouse evaluation of cultivars and germplasm accessions. Disease symptoms began to develop by 7 dpi with $P$. capsici

Table 2. Effects of bed height and cultivar on incidence of plant death $35 \mathrm{~d}$ post-inoculation (dpi) with Phytophthora capsici and area under the disease progress curve (AUDPC) averaged over mulches and poultry litter applications.

\begin{tabular}{lcclll}
\hline & \multicolumn{2}{c}{ Plant death (\%) 35 dpi } & & \multicolumn{2}{c}{ AUDPC $^{\mathrm{z}}$} \\
\cline { 2 - 3 } \cline { 5 - 6 } Bed ht & Cougar & Payroll & & Cougar & Payroll \\
\hline Flat & $99 \mathrm{a}^{\mathrm{x}}$ & $92 \mathrm{a}$ & & $2299 \mathrm{a}$ & $1760 \mathrm{a}$ \\
Raised & $100 \mathrm{a}$ & $83 \mathrm{~b}$ & & $2306 \mathrm{a}$ & $1510 \mathrm{~b}$ \\
Mean & 99 & 87 & & 2303 & 1635 \\
\hline
\end{tabular}

${ }^{\mathrm{z}}$ AUDPC was calculated for plant death incidence assessed at 7-d intervals from 0 to $35 \mathrm{dpi}$.

${ }^{\mathrm{y}}$ Beds were flat or raised $15 \mathrm{~cm}$ above the existing soil line.

${ }^{\mathrm{x}}$ For a given bed height $\times$ cultivar combination, values with a common letter do not differ significantly at $P \leq 0.01$ based on differences of least square means.

Table 3. Crown rot severity ratings for summer squash cultivars inoculated with Phytophthora capsici in greenhouse trials.

\begin{tabular}{|c|c|c|c|c|}
\hline$\overline{\text { Cultivar }}$ & Fruit type $^{z}$ & Fruit color ${ }^{y}$ & Seed source $^{x}$ & Crown rot severity $18 \mathrm{dpi}^{\mathrm{w}}$ \\
\hline Cougar & stra & $\mathrm{Y}$ & HM & 4.9 \\
\hline Spineless Perfection & zuc & G & Rog & 4.9 \\
\hline Golden Rod & zuc & Y & $\mathrm{HM}$ & 4.9 \\
\hline Payroll & zuc & G & Rog & 4.8 \\
\hline Golden Dawn III & zuc & $\mathrm{Y}$ & Rog & 4.8 \\
\hline Zucchini Elite & zuc & G & $\mathrm{HM}$ & 4.7 \\
\hline Fortune & stra & Y & Rog & 4.6 \\
\hline Multipik & stra & $\mathrm{Y}$ & $\mathrm{HM}$ & 4.6 \\
\hline Sunray & stra & Y & Sem & 4.6 \\
\hline Superpik & stra & Y & $\mathrm{HM}$ & 4.6 \\
\hline Felix & zuc & G & $\mathrm{HM}$ & 4.6 \\
\hline Noche & zuc & G & Rog & 4.6 \\
\hline Golden Glory & zuc & $\mathrm{Y}$ & Rog & 4.6 \\
\hline Golden Delight & zuc & Y & Rog & 4.6 \\
\hline Cheetah & stra & $\mathrm{Y}$ & Har & 4.5 \\
\hline Paycheck & zuc & G & Rog & 4.5 \\
\hline Supersett & croo & Y & $\mathrm{HM}$ & 4.4 \\
\hline Radiant & zuc & G & Sem & 4.4 \\
\hline Tigress & zuc & G & $\mathrm{HM}$ & 4.4 \\
\hline Zucchini Select & zuc & G & $\mathrm{HM}$ & 4.4 \\
\hline Senator & zuc & G & Sem & 4.4 \\
\hline Jaguar & zuc & G & Har & 4.3 \\
\hline Ishtar & mar & G & Sto & 4.3 \\
\hline Lioness & stra & $\mathrm{Y}$ & HM & 4.2 \\
\hline Bobcat & zuc & G & $\mathrm{HM}$ & 4.2 \\
\hline Leopard & zuc & G & $\mathrm{HM}$ & 4.2 \\
\hline Gold Rush & zuc & Y & Sem & 4.0 \\
\hline Reward & zuc & G & $\mathrm{HM}$ & 3.6 \\
\hline Cashflow & zuc & $\mathrm{G}$ & Rog & 3.2 \\
\hline Black Beauty & zuc & $\mathrm{G}$ & Sto & 3.1 \\
\hline Clarita & mar & G & Sto & 3.1 \\
\hline Spineless Beauty & zuc & G & Rog & 2.9 \\
\hline Mean & - & - & - & 4.3 \\
\hline Standard deviation & - & - & - & 0.53 \\
\hline FLSD $^{\mathrm{v}} \alpha=0.05$ & - & - & - & 0.99 \\
\hline
\end{tabular}

${ }^{\mathrm{z}}$ Squash type, where stra = straightneck; zuc = zucchini; croo = crookneck; mar = vegetable marrow.

${ }^{\mathrm{y}}$ Fruit color, where $\mathrm{Y}=$ yellow; $\mathrm{G}=$ green.

${ }^{\mathrm{x}} \operatorname{Rog}=$ Rogers Brand Vegetable Seeds, Syngenta Seeds Inc., Boise, ID; HM = Harris Moran Seed Co., Modesto, CA; Sem = Seminis Vegetable Seeds, Inc., St. Louis, MO; Har = Harris Seeds, Rochester, NY; Sto $=$ Stokes Seed Co., Thorold, Ontario, Canada .

${ }^{\text {w }}$ Crown rot severity was rated $18 \mathrm{~d}$ post-inoculation (dpi) on a 1 to 5 scale, where $1=$ no symptoms; $2=$ lower leaves wilted with slight constriction of the stem; $3=$ all leaves wilted with constriction and slight discoloration of the stem; $4=$ all leaves wilted and crown rotted with visible sporulation on the stem surface; and $5=$ plant dead. Values are the mean of two trials.

${ }^{\mathrm{v} F L S D}=$ Fisher's protected least significant difference.

\section{Discussion}

No combination of cultural practices adequately controlled Phytophthora crown rot in this study. Differences in cultivar susceptibility to $P$. capsici accounted for the most variation in disease levels in the field. In a similar study, red raspberry cultivars had the greatest effect on Phytophthora root rot levels in field trials evaluating multiple disease management practices (Wilcox et al., 1999). Results of this study demonstrate the importance of breeding summer squash cultivars with resistance to Phytophthora crown rot and the difficulty of managing this disease without fungicides. Cucurbit growers could integrate the use of resistant cultivars and fungicide applications to improve control of Phytophthora crown rot, which has been effective for managing this disease on pepper (Foster and Hausbeck, 2010b; Hwang and Kim, 1995). Although raised bed and mulch treatments did not significantly affect disease development in this study, growers should continue to use these practices in fields naturally infested with $P$. capsici because they improve soil drainage (Hausbeck and Lamour, 2004; Hwang and Kim, 1995; Ristaino and Johnston, 1999), reduce splash dispersal of soilborne inoculum (Ristaino et al., 1997), and improve yield (Bhella and Kwolek, 1984).

Resistance to $P$. capsici is necessary for the successful long-term management of Phytophthora crown rot of summer squash. Potential sources of resistance to $P$. capsici have recently been identified in certain Cucurbita germplasm accessions (Chavez et al., 2011; Padley et al., 2008). Stem lesions developed after inoculation with $P$. capsici

Table 4. Crown rot severity ratings for Cucurbita pepo and Cucurbita moschata accessions inoculated with Phytophthora capsici in greenhouse trials.

\begin{tabular}{llc}
\hline $\begin{array}{l}\text { Species and } \\
\text { accession }\end{array}$ & Origin & $\begin{array}{c}\text { Crown rot } \\
\text { severity } 18 \mathrm{dpi}^{\mathrm{z}}\end{array}$ \\
$\begin{array}{c}\text { Cucurbita pepo } \\
\text { PI 209783 }\end{array}$ & Germany & 3.8 \\
PI 512709 & Spain & 3.7 \\
PI 615132 & Mexico & 3.2 \\
PI 169417 & Turkey & 3.0 \\
PI 181761 & Lebanon & 2.1 \\
PI 615142 & Kazakhstan & 1.9 \\
Cucurbita moschata & & \\
PI 442262 & Mexico & 1.0 \\
PI 458740 & Paraguay & 1.0 \\
PI 442266 & Mexico & 1.0 \\
PI 634693 & India & 1.0 \\
Mean & - & 2.2 \\
SD & - & 1.2 \\
FLSD $\alpha=0.05$ & - & 1.1 \\
\hline
\end{tabular}

${ }^{\mathrm{z}}$ Crown rot severity was rated $18 \mathrm{~d}$ post-inoculation (dpi) on a 1 to 5 scale, where $1=$ no symptoms; $2=$ lower leaves wilted with slight constriction of the stem; $3=$ all leaves wilted with constriction and slight discoloration of the stem; $4=$ all leaves wilted and crown rotted with visible sporulation on the stem surface; and 5 = plant dead. Rating is the mean of two trials.

${ }^{\mathrm{y}} \mathrm{FLSD}=$ Fisher's protected least significant difference. 
on the six $C$. pepo accessions evaluated in this study. However, plants did not exhibit characteristic wilting symptoms. No symptoms developed after inoculation with $P$. capsici on four C. moschata (PI 442262, PI 458740, PI 442266, and PI 634693) accessions, which appear to possess high levels of Phytophthora crown rot resistance. Chavez et al. (2011) previously reported these accessions as potential sources of resistance to Phytophthora crown rot after inoculation with $P$. capsici isolates from Florida. Disease reactions can differ after inoculation with $P$. capsici isolates from different hosts as a result of physiological specialization (Lee et al., 2001; Ristaino, 1990). Plants in this study were inoculated with a single isolate of $P$. capsici originally recovered from pepper in Michigan. The accessions evaluated in this study could have different reactions to other isolates of $P$. capsici. Nevertheless, $P$. capsici isolate 12889 is highly virulent on multiple plant species and has been used in previous studies evaluating resistance to $P$. capsici in squash (Enzenbacher, 2011), pepper (Foster and Hausbeck, 2010a), tomato (Solanum lycopersicon L.) (QuesadaOcampo and Hausbeck, 2010), and fraser fir [Abies fraseri (Pursh) Poir.] (QuesadaOcampo et al., 2009). Additional studies are necessary to identify additional sources of $P$. capsici resistance in multiple Cucurbita species under greenhouse and field conditions.

Commercial summer squash cultivars differed in their reactions to Phytophthora crown rot. The cultivars Cougar (yellow straightneck) and Spineless Beauty (green zucchini) were the most and least susceptible to $P$. capsici, respectively. Similar results were observed in a field evaluation of summer and winter squash cultivars in New York (Camp et al., 2009). Evaluating cultivar reactions to Phytophthora crown rot in the greenhouse required less labor and space than field evaluations, which could be a limiting factor when evaluating large, vining cucurbits. Although no squash cultivars had complete resistance to $P$. capsici, cucurbit growers could use this information to select cultivars that are less susceptible to Phytophthora crown rot. Until resistant summer squash cultivars are available, growers should continue to combine fungicide applications and cultural practices to manage this disease.

\section{Literature Cited}

Babadoost, M. 2004. Phytophthora blight: A serious threat to cucurbit industries. APSnet Features.
Online. DOI: 10.1094/APSnetFeature-20040404.

Babadoost, M. 2005. Phytophthora blight of cucurbits. The Plant Health Instructor. DOI: 10.1094/PHI-I-2005-0429-01.

Babadoost, M. and T.A. Zitter. 2009. Fruit rots of pumpkin: A serious threat to the pumpkin industry. Plant Dis. 93:772-782.

Barksdale, T.H., G.C. Papavizas, and S.A. Johnston. 1984. Resistance to foliar blight and crown rot of pepper caused by Phytophthora capsici. Plant Dis. 68:506-509.

Bhella, H.S. and W.F. Kwolek. 1984. The effects of trickle irrigation and plastic mulch on zucchini. HortScience 19:410-411.

Camp, A.R., H.W. Lange, S. Reiners, H.R. Dillard, and C.D. Smart. 2009. Tolerance of summer and winter squash lines to Phytophthora blight, 2008. Plant Disease Management Reports 3:V022. Online publication. DOI: 10.1094/ PDMR03.

Chavez, D.J., E.A. Kabelka, and J.X. Chaparro. 2011. Screening of Cucurbita moschata Duchesne germplasm for crown rot resistance to Floridian isolates of Phytophthora capsici Leonian. HortScience 46:536-540.

Enzenbacher, T.B. 2011. An evaluation of cucurbits and ornamentals for susceptibility to Phytophthora spp. MS thesis, Michigan State University, East Lansing, MI

Foster, J.M. and M.K. Hausbeck. 2010a. Resistance of pepper to Phytophthora crown, root, and fruit rot is affected by isolate virulence. Plant Dis. 94:24-30.

Foster, J.M. and M.K. Hausbeck. 2010b. Managing Phytophthora crown and root rot in bell pepper using fungicides and host resistance. Plant Dis. 94:697-702.

Hausbeck, M.K. and K.H. Lamour. 2004. Phytophthora capsici on vegetable crops: Research progress and management challenges. Plant Dis. 88:1292-1303.

Hwang, B.K. and C.H. Kim. 1995. Phytophthora blight of pepper and its control in Korea. Plant Dis. 79:221-227.

Kabelka, E., L. Padley, Jr., P. Roberts, L. Ramos, M. Martinez, and K. Waldemar. 2007. Resistance to Phytophthora capsici within winter squash (Cucurbita moschata) derived from a wild Cucurbita species. HortScience 42:1014 (Abstr.).

Kimble, K.A. and R.G. Grogan. 1960. Resistance to Phytophthora root rot in pepper. Plant Dis. Rpt. 44:872-873.

Kousik, C.S., M.L. Adams, W.R. Jester, R. Hassell, H.F. Harrison, and G.J. Holmes. 2011. Effect of cultural practices and fungicides on Phytophthora fruit rot of watermelon in the Carolinas. Crop Prot. 30:888-894.

Lee, B.K., B.S. Kim, S.W. Chang, and B.K Hwang. 2001. Aggressiveness to pumpkin cultivars of isolates of Phytophthora capsici from pumpkin and pepper. Plant Dis. 85:497-500.

Lumsden, R.D., J.A. Lewis, and P.D. Millner. 1983. Effect of composted sewage sludge on several soilborne pathogens and diseases. Phytopathology 73:1543-1548.
Madden, L.V. and M.A. Ellis. 1990. Effect of ground cover on splash dispersal of Phytophthora cactorum from strawberry fields. J. Phytopathol. 129:170-174.

Núñez-Zofío, M., S. Larregla, and C. Garbisu. 2011. Application of organic amendments followed by soil plastic mulching reduces the incidence of Phytophthora capsici in pepper crops under temperate climate. Crop Prot. 30:1563-1572.

Padley, L.D., Jr., E.A. Kabelka, and P.D. Roberts. 2009. Inheritance of resistance to crown rot caused by Phytophthora capsici in Cucurbita. HortScience 44:211-213.

Padley, L.D., Jr., E.A. Kabelka, P.D. Roberts, and R. French. 2008. Evaluation of Cucurbita pepo accessions for crown rot resistance to isolates of Phytophthora capsici. HortScience 43:19961999.

Quesada-Ocampo, L.M., D.W. Fulbright, and M.K. Hausbeck. 2009. Susceptibility of Fraser fir to Phytophthora capsici. Plant Dis. 93:135141.

Quesada-Ocampo, L.M. and M.K. Hausbeck. 2010. Resistance in tomato and wild relatives to crown and root rot caused by Phytophthora capsici. Phytopathology 100:619-627.

Ristaino, J.B. 1990. Intraspecific variation among isolates of Phytophthora capsici from pepper and cucurbit fields in North Carolina. Phytopathology 80:1253-1259.

Ristaino, J.B. and S.A. Johnston. 1999. Ecologically based approaches to management of Phytophthora blight on bell pepper. Plant Dis. 83:1080-1089.

Ristaino, J.B., G. Parra, and C.L. Campbell. 1997. Suppression of Phytophthora blight in bell pepper by a no-till wheat cover crop. Phytopathology 87:242-249.

Sang, M.K., J.-G. Kim, and K.D. Kim. 2010. Biocontrol activity and induction of systemic resistance in pepper by compost water extracts against Phytophthora capsici. Phytopathology 100:774-783.

Shaner, G. and R.E. Finney. 1977. The effect of nitrogen fertilization on the expression of slowmildewing resistance in Knox wheat. Phytopathology 67:1051-1056.

Springer, J.K. and S.A. Johnston. 1982. Black polyethylene mulch and Phytophthora blight of pepper. Plant Dis. 66:281.

Vawdrey, L.L., K.E. Grice, R.A. Peterson, and J. De Faveri. 2004. The use of metalaxyl and potassium phosphonate, mounds, and organic and plastic mulches, for the management of Phytophthora root rot of papaya in far northern Queensland. Australas. Plant Pathol. 33:103107.

Waterhouse, G.M. 1963. Key to the species of Phytophthora de Bary. Mycol. Pap. 92:1-22.

Wilcox, W.F., M.P. Pritts, and M.J. Kelly. 1999. Integrated control of Phytophthora root rot of red raspberry. Plant Dis. 83:1149-1154.

Zinati, G.N. 2005. Compost in the 20th century: A tool to control plant diseases in nursery and vegetable crops. HortTechnology 15:6166. 